\title{
A Review on Green Purchase Behaviour Trend of Malaysian
} \section{Consumers}

\author{
Yen-Nee Goh $^{1}$ \& Nabsiah Abdul Wahid ${ }^{1}$ \\ ${ }^{1}$ Graduate School of Business, Universiti Sains Malaysia, Malaysia \\ Correspondence: Yen-Nee Goh, Graduate School of Business, Universiti Sains Malaysia, 11800, USM, Penang, \\ Malaysia. Tel: 60-4-653-5294. E-mail: yngoh@usm.my
}

\author{
Received: August 4, 2014 Accepted: October 27, 2014 Online Published: December 20, 2014 \\ doi:10.5539/ass.v11n2p103 URL: http://dx.doi.org/10.5539/ass.v11n2p103
}

\begin{abstract}
The emergence of environmental problems and the increased awareness towards green purchase behaviour have received many responses by the stakeholders' worldwide like from the government bodies, researchers, businesses, consumers and so on. Government's bodies, for example, have responded by developing and introducing their own environmentally-linked policies to be implemented in their countries, which are intended to conserve and preserve the environment. Researchers, on the other hand, are continuously conducting extensive studies and publishing their findings on the issues to inform the public, while businesses that promote the selling of green products (or environmentally friendly products) in the marketplace have been increasing in number. Segments of green consumers have been observed to emerge and grow in size worldwide including Malaysia. This may be due to the increased number of green products introduced to consumers in the marketplace. Moreover, scholars from Malaysia also argued that, this trend is experiencing tremendous growth. Although there are responses from these stakeholders, especially consumers, who have had a positive impact on the environment, the trend of the green purchase behaviour by Malaysian consumers remains unobserved. Therefore, the authors aim to answer the questions concerning whether a trend can be observed in the green purchase behaviour of Malaysian consumers. The ability to observe the green purchase behaviour trend is useful, particularly for marketers and businesses that are selling or intending to sell green products within the country.
\end{abstract}

Keywords: green purchase behaviour, consumer, Malaysia

\section{Introduction}

\subsection{The Conceptualisation of Green Product}

Nowadays, to be labelled 'green' has become an important positioning strategy for many businesses as the ability to gain such status somehow help them to be perceived as the 'good guys' or 'knights in shining armour' for the environment. Thus, being green has turned out to be the trend among businesses by offering their own brand of green products-or what they refer to as the environmentally friendly products. Through Google search engine, a search on 1 February 2013 for the term "Green Products" alone found more than 1.5 million potential sites that provide viewers with various definitions and descriptions of green products. These definitions include products that are environmentally preferable relative to comparable products that have less impact on the environment and are less harmful to human health, and products that meet the quality criteria of protecting the environment, such as by replacing artificial ingredients with natural ingredients. On the other hand, from the academic point of view, green products can be referred to as a product that does not cause pollution to the environment or resource depletion as well as being recyclable and conservable (Said et al., 1993). Hence, green products can also be referred to as environmentally friendly products that have minimum impact on the environment, such as by using less toxic ingredients. These green products include those that are recyclable, degradable, have longer life, better quality, energy efficient, result in cost savings, and made of materials that can be recycled. Online websites like ecofriend.com.my and philips.com describe green products based on the $3 \mathrm{R}$ principle (reuse, reduce and recycle) or on its energy savings green products, respectively. In general, the definition of green product varies depending on the author's focus, whether it is on green or environmentally related literature in which they believe will help provide a better understanding of the issue.

Similar to the Google exercise carried out earlier, the authors found many versions of green products which were described in the literature. These were then categorized based on the technical characteristics of the product, 
specific features and material used to justify the definitions of green products. From the list of technical characteristics of green products, Nimse et al. (2007) have listed the following ten technical characteristics of such products:

1) Made from natural and/or renewable resources

2) Bio-degradable

3) Locally obtained

4) Easily reused

5) No Chlorofluorocarbons (CFCs), Hydro chlorofluorocarbons (HCFCa) or other ozone depleting substances

6) Readily recycled

7) No environment degrading toxic chemicals or by-products in its life cycle.

8) Incorporates recycled content

9) Promotes good indoor air quality

10) Durable, low maintenance

In terms of specific features, Mishra and Sharma (2010) suggested that green products can also be based on whether they are grown naturally, whether there is usage of natural ingredients, whether there is usage of approved chemicals, whether animal testing was carried out and whether the products do not pollute the environment. As for the materials used, Alsmadi (2007) stated that green products are those that use environmentally friendly materials, minimum energy and resource consumption and are subject to recycling; or as he defined them-these are products that do not cause any harm to the environment. Tan and Lau's (2010) view seem to run parallel with Alsmadi (2007) they also described green products as environmentally friendly products or an ecological product that incorporates recycling strategies (i.e. recycled content) using minimal packaging and less toxic materials to help mitigate the harmful effect to the natural environment.

From all the definitions and descriptions (whether technical or non-technical) given or found in the literature on green products earlier, the authors revealed various ways that were used to define green products. Accordingly, for the purpose of this study, it could be summarized that green product are products with specific characteristics that are environmentally friendly so that they do not cause any harm to the environment.

\section{Definitions of Green Purchase Behaviour and Its Determinants}

The review of past literature has identified quite a number of studies that focus on green purchase behaviour. Some of the studies were carried out in countries like the United States of America, United Kingdom, China, Egypt, Pakistan and Malaysia. However, similar to green products, it was quite difficult to find a unanimous definition of green purchase behaviour among researchers. Mostafa (2007), for instance, defined green purchase behaviour as environmentally friendly buying behaviour or the consumption of products that benefits the environment, conservable, recyclable, responsive and sensitive to the concern of ecological matters. Chan (2001) defined it as environmentally friendly behaviour expressed by consumers in showing their interest towards the environment whereas Nik Abdul Rashid (2009) described it as the probability and willingness of individuals who give preference to products that contain features that are environmentally friendly when compared to the purchase of other traditional products.

There is a wealth of empirical evidence from studies conducted in developed and developing countries worldwide that suggest that green purchase behaviour is influenced by a number of factors like culture, value orientation, environmental concern, knowledge, attitude and demographic factors (e.g. age, gender, income level and so on). In addition, an integrated conceptual framework that covers a total of eight factors or aspects of green issues that are likely to have an impact on consumer green purchasing behaviour has also been proposed by Kauffman et al. (2012). The eight factors include: environmental knowledge, altruism, environmental awareness, environmental concern and attitude, availability of product information and belief about product safety for use, perceived consumer effectiveness, collectivism and transparency and fairness concerning business practices. Kauffman et al. (2012) also proposed demographic variables such as age, gender, income level, education level, ethnicity and occupation as the mediator in this framework. In brief, the authors of this study concur with the proposed framework identified by Kauffman et al. (2012), which has in fact been observed to cover most of the determinants of green purchase behaviour found by previous studies. The following section discusses the determining factors of green purchase behaviours. 


\subsection{Value Orientation}

The authors also identified that value orientation is a determinant that needs to be highlighted. Kim and Choi (2005), who argued that collectivistic orientations can influence different social behaviour, proved through their study on Korean consumers, that collectivism (an individual level value orientation) is indeed very influential not only on an individual's intention to buy green products, but also on their motivation to be involved in environmentally conscious behaviour. In a similar vein, McCarthy and Shrum (2001) found that collectivism positively impacted on consumers' recycling and their recycling behaviour. According to these researchers, consumers with individualistic tendencies viewed recycling as less important but those who are collectivistic, have a higher tendency to cooperate, are willing to help others and stressed achieving group goals rather than personal goals (McCarthy \& Shrum, 2001).

\subsection{Response towards Environmental Wellness}

The authors noted that previous studies on green purchase behaviour enlisted customers' response towards environmental wellness such as environmental concern, knowledge and attitude as the determinants of behaviour In Kim and Choi's (2005) study on Korean consumers found that, environmental concern is positively related to green purchase behaviour among consumers who have shown greater concern towards the environment. Whereas Mostafa's (2006) study on Egyptian consumers' green purchase intentions found that several factors describe the customers' response such as environmental knowledge, environmental concern, attitude towards green products, perceived consumer effectiveness, altruism and scepticism towards environmental claims-acted as the antecedents of intention. Mostafa (2007) in another study reported that, a great number of Egyptian consumers have showed more concern about the ecological situation and they are willing to contribute by buying green products. Similar to Mostafa's $(2006,2007)$ findings in Pakistan, by Ali at al. (2011) revealed that green purchase attitude is positively correlated to consumers' green purchase intention and that intention is positively correlated to their green purchase behaviour. In addition, Ali et al. (2011) highlighted that individuals who are concerned about the environment and believed pollution to be a problem will display a positive attitude towards a green environment. Moreover, these individuals will have a tendency for green product purchasing, and that they come from those who are educated (Ali et al., 2011).

\subsection{Demographics Profile of Consumers}

A review on previous studies found that demographic factors have a significant effect on consumers' green purchase behaviour. In Kollmuss and Agyeman's (2002) study, demographic factors appeared to be one of the most influential factors in pro-environmental behaviour. Research reveals that age, gender, income level, education level and occupation are the demographic characteristic that significantly influences the consumers (cited from Kauffman et al., 2012). In Malaysia, certain demographics have also been found to play an important role in regard of green purchase behaviour. Age, for example, is significant, as shown in Sinnappan and Abdul Rahman's (2011) study, where they found that the age group of 20 years and below (adolescence) played a more influential role compared to the other age groups (i.e. 20 to 25 years old, 26 to 30 years old, 31 to 35 years old, 36 to 40 years old and 40 years above) in green purchase behaviour. In another research which was conducted on undergraduate students from a major private university in Malaysia, Tan and Lau (2010) found no significant difference between male and female students' attitudes concerning green products. However, a study conducted in the Klang Valley, Malaysia, by Rezai, Mohamed and Shamsudin (2011) found that females are more likely to purchase green product such as organic food than males. Additionally, the assumption that those with a higher level of education will impact positively on green purchase behaviour is also shared overseas. For example, in Pakistan, Ali et al. (2000) followed by Ahmed and Shahzad's (2011) testified that consumers who are educated have a positive attitude regarding green products and are willing to buy green product(s).

\section{Predictor of Green Product Purchasing in Malaysia}

The review on the existing literature, indicated that the trend of green purchase behaviour of consumers is closely influenced by a few determining factors. While this is so, the question remains as to whether the same situation applies for consumers in Malaysia. The authors found a few studies that emphasised this issue and which may provide the answer. It is only when the authors scrutinized related studies on green purchase behaviour carried out in Malaysia, e.g. studies by Abdul Wahid, Rahbar and Tan (2011); Ooi, Kwek and Keoy (2012); Sinnappan and Abdul Rahman (2011), and Tsen, Phang, Hasan and Buncha (2006) that the answer was found to the question posed earlier, i.e. whether or not we can observe a trend on green purchase behaviour by Malaysian consumers. However, similar to the studies conducted overseas, the type of green product purchase investigated by researchers in Malaysia varies. While some did not specify what the green products are (in this case, they use general green product) just like in the case of Abdul Wahid et al. (2011), others specified the type 
of green product. For example, Ahmad and Juhdi (2010) identified green products as organic products like rice, grain or bakery products, organic fruits and vegetables, organic dairy products, as well as meat, poultry and eggs. In brief, the type of green product purchase varies among the previous studies. Table 1 shows a summary of research findings for green purchase behaviour in Malaysia.

Table 1. Sample of research findings for green purchase behaviour in Malaysia

\begin{tabular}{|c|c|c|}
\hline Determining Factor & Author & $\begin{array}{l}\text { Observed Trend-Who will be more } \\
\text { likely to make a green purchase }\end{array}$ \\
\hline Age & Sinnappan and Abdul Rahman (2011) & $\begin{array}{l}\text { Consumers aged below } 20 \text { years } \\
\text { (adolescents) compared to other age } \\
\text { groups }\end{array}$ \\
\hline Gender & $\begin{array}{l}\text { Rezai, Mohamed and Shamsudin (2011); Ahmad } \\
\text { and Juhdi (2010); Abdul Wahid, Rahbar and Tan } \\
\text { (2011) }\end{array}$ & Females rather than males \\
\hline Marital status & Ahmad and Juhdi (2010), Alodini (2008) & Married compared to unmarried \\
\hline Education level & $\begin{array}{l}\text { Ahmad and Juhdi (2010); Abdul Wahid, Rahbar } \\
\text { and Tan (2011); Alodini (2008) }\end{array}$ & $\begin{array}{l}\text { Highly educated consumers rather than } \\
\text { uneducated or those with low level of } \\
\text { education }\end{array}$ \\
\hline Income level & $\begin{array}{l}\text { Ahmad and Juhdi (2010), Abdul Wahid, Rahbar } \\
\text { and Tan (2011) }\end{array}$ & $\begin{array}{l}\text { High income earners compared to } \\
\text { non-high income earners }\end{array}$ \\
\hline Price & Rezai, Mohamed and Shamsudin(2011) & Can influence purchase behaviour \\
\hline Ethnicity & Ahmad and Juhdi (2010) & Chinese rather than other ethnic groups \\
\hline Brand perception & Wong (2010) & $\begin{array}{l}\text { Consumers who perceive brand as } \\
\text { green brand }\end{array}$ \\
\hline $\begin{array}{l}\text { Social influence, Peer } \\
\text { pressure }\end{array}$ & $\begin{array}{l}\text { Abdul Wahid, Rahbar and Tan (2011); Ooi, Kwek } \\
\text { and Keoy (2012) }\end{array}$ & $\begin{array}{l}\text { Consumers that are influenced by } \\
\text { social groups }\end{array}$ \\
\hline $\begin{array}{l}\text { Attitude, environmental } \\
\text { concern }\end{array}$ & $\begin{array}{l}\text { Alodini (2008); Abdul Wahid, Rahbar and Tan } \\
\text { (2011); Sinnappan and Abdul Rahman (2011); } \\
\text { Tsen, Phang, Hasan and Buncha (2006) }\end{array}$ & $\begin{array}{l}\text { Consumers with positive attitude and } \\
\text { high concern for the environment }\end{array}$ \\
\hline $\begin{array}{l}\text { Green } \\
\text { knowledge }\end{array}$ & Abdul Wahid, Rahbar and Tan (2011) & $\begin{array}{l}\text { Consumers with knowledge on green } \\
\text { products compared to those with no } \\
\text { knowledge }\end{array}$ \\
\hline $\begin{array}{l}\text { Specific environmental } \\
\text { knowledge }\end{array}$ & Abdul Wahid, Rahbar and Tan (2011) & $\begin{array}{l}\text { Consumers with specific knowledge on } \\
\text { environment compared to those with no } \\
\text { knowledge on the subject }\end{array}$ \\
\hline Environmental label & Abdul Wahid, Rahbar and Tan (2011) & $\begin{array}{l}\text { Consumers who believe in } \\
\text { environmental label }\end{array}$ \\
\hline $\begin{array}{l}\text { Environmental } \\
\text { responsibility }\end{array}$ & Sinnappan and Abdul Rahman (2011) & $\begin{array}{l}\text { Consumers who perceive that they } \\
\text { have responsibility towards } \\
\text { environment }\end{array}$ \\
\hline $\begin{array}{l}\text { Perceived seriousness of } \\
\text { environmental problems }\end{array}$ & Sinnappan and Abdul Rahman (2011) & $\begin{array}{l}\text { Consumers who perceive that the } \\
\text { environmental problems they face are } \\
\text { serious }\end{array}$ \\
\hline $\begin{array}{l}\text { Perceived effectiveness } \\
\text { of } \quad \text { environmental } \\
\text { behaviour }\end{array}$ & Sinnappan and Abdul Rahman (2011) & $\begin{array}{l}\text { Consumers who perceive that } \\
\text { environmental behaviour is effective }\end{array}$ \\
\hline Government's role & $\begin{array}{l}\text { Sinnappan and Abdul Rahman (2011); Ooi, } \\
\text { Kwek and Keoy (2012) }\end{array}$ & $\begin{array}{l}\text { Consumers who perceive that the } \\
\text { government plays a role }\end{array}$ \\
\hline Collectivism value & Tsen, Phang, Hasan and Buncha (2006) & $\begin{array}{l}\text { Consumers who have high collectivism } \\
\text { value }\end{array}$ \\
\hline Local people & Alodini (2008) & $\begin{array}{l}\text { Local (student) consumers rather than } \\
\text { foreigners }\end{array}$ \\
\hline
\end{tabular}

Source: Self-developed

4. General Trends among Malaysian Consumers in Purchasing Green Product 
It is observed that the general trend among the consumers in Malaysia tend to be different based on the different geographical location, for instance in Peninsula Malaysia and Sabah. In Peninsula Malaysia, consumers' demographics profile (i.e. age) seems to play an important role. Sinnappan and Abdul Rahman's (2011) study examined the antecedents of green purchase behaviour and observed whether the factors influencing green purchase behaviour will be different based on consumers' demographic profile, such as age group, education level, ethnic group, type of occupation and income level. The empirical findings revealed that among the antecedents, environmental attitudes stand out as one of the most sought after factor for green purchasing behaviour. Other predictors include perceived environmental responsibility, environmental concern, perceived seriousness of environmental problems, perceived effectiveness of environmental behaviour and the government's role (Sinnappan \& Rahman, 2011). Moreover, it is proven that age is significant in explaining the environmental factors (Sinnappan \& Rahman, 2011). In this study, questionnaires were distributed within Peninsular Malaysia. A total of 204 usable questionnaires were used for data analysis. Respondents were consumers from various age groups, educational levels, ethnic groups, types of occupation and income levels. Only age group was found to be significant in explaining the environmental factors. The computed mean showed that respondents who were less than 20 years old considered the factors to be highly important to them compared to adults. The younger generation, who are adolescents, were found to portray stronger perceptions concerning environmental factors compared to adults, which indicates that this adolescent group is the green market to be penetrated in the future.

Another studies by Ooi, Kwek and Keoy (2012) and Ooi, Kwek and Tan (2012) found that environmental knowledge, environmental attitude, peer pressure and government initiative showed a significant influence on the green purchase intention of Malaysian consumers although surprisingly, eco-labels did not indicate any significant relationship to the green purchase intention of Malaysian consumers. The study of Ooi, Kwek and Keoy (2012) was carried out on respondents who were Malaysian green products users. A total of 230 usable questionnaires were used and analysed for statistical tests.

There are also some empirical findings from a research conducted in Penang, for example among the Penang green volunteers, students at Universiti Sains Malaysia, who could also be categorised as Generation Y. Among the Penang green volunteers, Abdul Wahid et al. (2011) found that the practice of green purchase behaviour amongst them is still low, although these volunteers seemed to show a satisfactory level of environmental knowledge except concerning the knowledge related to the issue of waste. Interestingly, however, is the discovery of six significant factors that affected the respondents' green purchase behaviour-social influence, environmental concern, green product knowledge, specific environmental knowledge, environmental label and income level. In this study, 300 questionnaires were distributed to volunteers in Penang who participated in environmentally related activities regardless of whether they were attached to any organization or not. Their respondents' profile showed that the majority of the sample respondents were comprised of 21-40 year olds (77\%), female gender (61\%), Chinese ethnicity (78\%), single/not married individuals (50.5\%), individuals with high education background, i.e. at least Bachelor degree and above (80\%), and individuals with a monthly gross personal income between RM1501 and RM4500 (48\%) (Note 1).

Meanwhile, a number of unpublished theses by postgraduate students, which also carried out research similar to the green purchase behaviour, were identified and analysed. For example, an unpublished MBA thesis by Tan (2010) concerning the influence of the green purchase behaviour of environmentally related volunteers in Penang, found that social influence, environmental concern, green product knowledge and specific environmental knowledge (i.e. two of the dimensions in environmental knowledge), environmental label and income level would significantly affect the green purchase behaviour of the green volunteers.

Among the Generation ' $Y$ ', Wong (2010) carried out a study to examine the factors affecting Malaysian generation $Y$ ' green brand perception and purchase decision. In her research, she attempted to determine factors that have a significant effect on the perception of green brand under the influence of premium price, simple green message setting, excessive green message setting, consistency between green brand personality and firm's green principles and subject's environmental consciousness. She also intended to investigate the role of moderating factors, such as gender and educational level on the influence of the relationship between five independent variables and green brand perception. Consecutively, she attempted to study the relationship between green brand perception and purchase decision. This research adopted a quantitative approach in which the questionnaires were distributed and collected among a sample of 256 respondents. Her study results showed that premium price, simple green message setting and subject's environmental consciousness were significantly related to green brand perception. Nevertheless, gender and educational level were not found to have a significant moderating effect on independent variables and green brand perception. However, green brand 
perception was found to be significantly related to purchase decision.

Among the students, Alodini (2008) investigated factors that influence students in paying more for environmentally friendly products. This study was carried out among 342 students in Universiti Sains Malaysia, showed that consumers' attitude and behaviour were the most consistent factors predicting willingness to pay more for green products. The research finding also showed that the segment of consumers who were willing to pay extra for green products was more likely to be married. Another finding showed that local students show more willingness to pay for environmentally friendly products compared to international students.

On the other hand, in Sabah, scholars confirmed two major empirical findings; the first is that consumer attitude is one of the consistent explanatory predictors for willingness to pay for green products among the consumers in Kota Kinabalu, Sabah. The second finding by Tsen et al. (2006) confirmed the existence of a significant relationship between the collectivism value and willingness to pay for green products among the consumers in Kota Kinabalu, Sabah. In this study, 300 questionnaires were distributed to consumers around Kota Kinabalu; 250 questionnaires were returned. The majority of the respondents were aged between 21-30 years (61.7\%), female (68.5\%), still single (6.2\%), with bachelor degree (50\%) and currently had 4 to 6 people living with them. Their research confirmed two major empirical findings; the first is that consumer attitude is one of the consistent explanatory predictors for willingness to pay for green products among the consumers in Kota Kinabalu, Sabah. To be specific, Tsen et al.'s (2006) study confirmed that all four dimensions of consumer environmental attitude, except for level of responsibility of corporations, had a positive relationship with consumer's willingness to pay for environmentally friendly products. Consumer environmental attitudes were measured in four dimensions: i) understanding of the severity of environmental problems, ii) importance of being environmentally friendly, iii) level of responsibility of corporations, and iv) inconvenience of being environmentally friendly. The second finding by Tsen et al. (2006) confirmed the existence of a significant relationship between the collectivism value and willingness to pay for green products among the consumers in Kota Kinabalu, Sabah. Here, collectivism was categorized as one of the sub variables in consumer value. Similar results have also been identified from other empirical past findings, such as by Follows and Jobber (2000), and Laroche et al. (2001).

\section{Conclusion}

In conclusion, this chapter has provided an insight into the trend of green purchase behaviour of Malaysian consumers. Based on the review of both global and local studies that have been published in the literature, the overall trend of green purchase behaviour was observed to be triggered by several factors, such as culture, value orientation, environmental concerns, knowledge, attitude and demography. Although this is so, it is believed that there are differences between countries in the determining factors for green purchase behaviour when cultural and economic conditions are taken into the context of the study. In Malaysia, while the behaviour is observed to be still low, the trend shows that for those who adopted it like those who are married and those who believe in the value of collectivism, pricing did not seem to be a concern for them to make a purchase. Additionally, the authors believed that the ability to observe the green purchase behaviour trend is useful, particularly for marketers and businesses that are selling or intending to sell green products in Malaysia. It is believed that the insights provided in this chapter will indirectly encourage more research on this topic to be carried out, particularly for the emerging markets, like Malaysia, and also other South East Asian countries.

\section{References}

Ahmad, S. N. B., \& Juhdi, N. (2010). Organic Food: A Study on Demographic Characteristics and Factors Influencing Purchase Intentions among Consumers in Klang Valley, Malaysia. International Journal of Business and Management, 5(2), 105-118. http://dx.doi.org/10.5539/ijbm.v5n2p105

Ali, A., Khan, A. A., Ahmed, I., \& Shahzad, W. (2011). Determinants of Pakistani consumers' green purchase behaviour: Some insights from a developing country. International Journal of Business and Social Science, 2(3), 217-226. Retrieved from http://ijbssnet.com/journals/Vol._2_No._3_\%5BSpecial_Issue_-_January _2011\%5D/26.pdf

Alodini, A. A. (2008). Factors that influence customers to pay more for environmentally friendly products (going green) in Universiti Sains Malaysia. Unpublished MBA thesis. Universiti Sains Malaysia.

Alsmadi, S. (2007). Green marketing and the concern over the environment: Measuring environmental consciousness of Jordanian consumers. Journal of Promotion Management, 13(3-4), 339-361. http://dx.doi. org/10.1080/10496490802306905

Asian Productivity Organization. (2011). Number of listed products and services by category. Retrieved from http://www.apo-tokyo.org/00e-books/GP-22_EcoProDir2011/EcoProDir2011_FINAL.pdf 
Chan, R. K. Y., \& Lau, L. B. Y. (2001). Explaining green purchasing behaviour: A cross cultural study on American and Chinese consumers. Journal of International Consumer Marketing, 14(2/3), 9-40.

Chan, R. Y. K. (2001). Determinants of Chinese consumers' green purchase behaviour. Psychology and Marketing, 18(4), 389-413. http://dx.doi.org/10.1002/mar.1013

Crane, A. (2000). Facing the backlash: Green marketing and strategic reorientation in the 1990s. Journal of Strategic Marketing, 8, 277-296. http://dx.doi.org/10.1080/09652540050110011

Follows, S. B., \& Jobber, D. (2000). Environmentally responsible purchase behaviour: A test of a consumer model. European Journal of Marketing, 34, 723-746. http://dx.doi.org/10.1108/03090560010322009

Kaufmann, H. R., Panni, M. F. A. K., \& Orphanidou, Y. (2012). Factors affecting consumers' green purchasing behaviour: An integrated conceptual framework. Amfiteatru Economic, 15(31), 50-69. Retrieved from http://www.amfiteatrueconomic.ase.ro/english/archive.html

Kim, Y., \& Choi, S. M. (2005). Antecedents of green purchase behaviour: An examination of collectivism, environmental concern and PCE. Advances in Consumer Research, 32, 592-599. Retrieved from http://eds.a.ebscohost.com/ehost/pdfviewer/pdfviewer?vid=3\&sid=466c5f15-f9c1-451b-9190-981f53a852a a\%40sessionmgr4005\&hid $=4210$

Kollmuss, A., \& Agyeman, J. (2002). Mind the gap: Why do people act environmentally and what are the barriers to pro-environmental behaviour? Environment Education Research, 8(3), 239-260. http://dx.doi.org $/ 10.1080 / 13504620220145401$

Laroche, M., Bergeron, J., \& Barbaro-Forleo, G. (2001). Targeting consumers who are willing to pay more for environmentally friendly products. Journal of Consumer Marketing, 18, 503-520. http://dx.doi.org/10.1108/ EUM0000000006155

Lee, K. (2008). Opportunities for green marketing: Young consumers. Market Intelligence Planning, 26, 573-586. http://dx.doi.org/10.1108/02634500810902839

McCarthy, J. A., \& Shrum, L. J. (2001). The influence of individualism, collectivism and locus of control on environmental beliefs and behaviour. Journal of Public Policy and Marketing, 20, 93-104. http://dx.doi.org /10.1509/jppm.20.1.93.17291

Md Harizan, S. H., \& Haron, M. S. (2012). Green Product Purchase Behaviour: Relevance for Muslims. Chinese Business Review, 11(4), 377-382. Retrieved from http://search.proquest.com/docview/1465963571? accountid $=14645$

Mishra, P., \& Sharma, P. (2010). Green marketing in India: emerging opportunities and challenges. Journal of Engineering, Science and Management Education, 3, 9-14. Retrieved from http://14.139.58.2/ejournalver2 /abstract/year2010/volume3/PavanMishraandMs.PayalSharma.pdf

Mostafa, M. M. (2007). Gender differences in Egyptian consumers green purchase behaviour: The effects of environmental knowledge, concern and attitude. International Journal of Consumer Studies, 31, 220-229. http://dx.doi.org/10.1111/j.1470-6431.2006.00523.x

Nimse, P., Vijayan, A., Kumar, A., \& Varadarajan, C. (2007). A review of green products database. Environmental Progress, 26(2), 131-137. http://dx.doi.org/10.1002/ep.10210

Ooi, J. M., Kwek, C. L., \& Keoy, K. H. (2012). The antecedents of green purchase intention among Malaysian consumers. Proceeding in the International Conference on Economics, Business Innovation (pp. 38-43). IACSIT, Singapore. Retrieved from http://www.ipedr.com/vol38/008-ICEBI2012-A00014.pdf

Ooi, J. M., Kwek, C. L., \& Tan, H. P. (2012). The antecedents of green purchase intention among Malaysian consumers. Asian Social Science, 8(13), 248-263. http://dx.doi.org/10.5539/ass.v8n13p248

Rashid, N. R. N. A. (2009). Awareness of eco-label in Malaysia's green marketing initiative. International Journal of Business and Management, 4(8), 132-141. http://dx.doi.org/10.5539/ijbm.v4n8p132

Rezai, G., Mohamed, Z., \& Shamsudin, M. N. (2011). Malaysian consumer's perception towards purchasing organically produces vegetable. Proceedings of the $2^{\text {nd }}$ International Conference on Business and Economics Research (pp. 1774-1783). Malaysia.

Said, A. M., Ahmadun, F. R., Paim, L. H., \& Masud, J. (2003). Environmental concerns, knowledge and practices gap among Malaysian teachers. International Journal of Sustainability Higher Education, 4, 305-313. http://dx.doi.org/10.1108/14676370310497534 
Sinnappan, P., \& Abdul Rahman, A. (2011). Antecedents of green purchasing behaviour among Malaysian consumers. International Business Management, 5(3), 129-139. http://dx.doi.org/10.3923/ibm.2011.129.139

Tan, B. C., \& Lau, T. C. (2010). Attitudes towards the environment and green products. Management Science and Engineering, 4(2), 27-39.

Tan, S. S. (2010). Factors influencing the green purchase behaviour of environmental related volunteers in Penang. Unpublished MBA thesis. Universiti Sains Malaysia.

Tsen, C. Y., Phang, G., Hasan, H., \& Buncha, M. R. (2006). Going green: A study of consumers' willingness to pay for green products in Kota Kinabalu. International Journal of Business and Society, 7(2), 40-54. Retrieved from http://www.myjurnal.my/filebank/published_article/14506/ARTICLE3.pdf

Wahid, N. A., Rahbar, E., \& Tan, S. S. (2011). Factors influencing green purchase behaviour of Penang environmental volunteers. International Business Management, 5(1), 38-49. http://dx.doi.org/10.3923 /ibm.2011.38.49

Wong, W. K. (2010). Factors affecting Malaysian generation Y's green brand perception and purchase decision. Unpublished MBA thesis. Universiti Sains Malaysia.

\section{Note}

Note 1 . The rest of the $39 \%$ were earning at least RM4501 per month gross personal income.

\section{Copyrights}

Copyright for this article is retained by the author(s), with first publication rights granted to the journal.

This is an open-access article distributed under the terms and conditions of the Creative Commons Attribution license (http://creativecommons.org/licenses/by/3.0/). 